\title{
EXAMINATION OF CHINESE "CHOPSTICKS" MERCANTILIST POLICIES IN AFRICA
}

\section{Semanur Soyyiğita ${ }^{a}$, Murat Nişancı ${ }^{b}(i)$}

\begin{abstract}
It is a theoretical fact that countries in which foreign direct investments (FDI) are realized by trans-national corporations for the purpose of profit should have some economical and institutional pull factors. This study examines whether Chinese FDI in African countries is supported theoretically by the economic and institutional factors of these African countries or whether these investments instead serve mercantilist policies of China independently of these factors. With this in mind, we examined the effect of the GDP, trade openness, natural resource rents and some institutional indicators of the host African countries on the Chinese foreign direct investments within the period 2003-2017 for 10 African countries. We used Swamy's random coefficient panel regression method due to the heterogeneity of these 10 African countries. The empirical results show that China makes foreign direct investments in Africa for market and resource-seeking purposes which display significant elements of a "chopsticks" mercantilist policy.
\end{abstract}

Keywords: foreign direct investments, mercantilism, economic development JEL Classifications: F21, B11, F63

\section{Introduction}

The protectionist approach to foreign trade was the main feature of the mercantilist period that started with the discovery of the New World and the settlement of European colonies, especially the Spanish and the Portuguese, and lasted until the Industrial Revolution. In this period, which lasted approximately 300 years, economic policies were seen as a part of a country's national goals. Following the Industrial Revolution, mercantilism was replaced by classical thought that advocated liberal policies in international economic relations. However, mercantilism tried to find its place under the dominance

a Kirklareli University, Faculty of Economics and Administrative Sciences, Department of Public Finance, Kirklareli, Turkey

b Erzincan Binali Yıldırım University Yalnızbağ Campus Faculty of Economics and Administrative Sciences Department of Economics, Erzincan,Turkey

E-mail: semanur.soyyigit@klu.edu.tr; mnisanci@erzincan.edu.tr 
of the liberal paradigm and has re-emerged within the framework of a structure called neo-mercantilism, which differs from classical mercantilism. Neo-mercantilism is based on the market structure and the determination of prices in the market mechanism. Moreover, certain aspects of militarism in classical mercantilism have largely disappeared in neo-mercantilism (Okeke, 2016:183).

In neo-mercantilist thought, wage and employment policies are ones that should not be ignored in today's globalized world. Landreth and Colander (2002) state that from this perspective, the wealth of a nation is based on the poverty of its masses. According to this, mercantilists express that a country's competitive advantage in international trade can be achieved by low wages and that a wage level above the minimum wage will decrease the productivity of the labour force. High wages will result in fewer hours of labour per year and reduced national output. In mercantilist thinking, the purpose of economic activity is production rather than consumption and a decrease in national production means a decrease in exportable value (Landreth and Colander, 2002:47). Since the second half of the twentieth century, as the development of institutional quality and welfare have increased in Western countries, there has been a proportionate increase in the wage levels of those countries. With globalization, however, the capital in these countries then began to shift to regions where labour force was relatively cheaper. Through trans-national corporations, capital has shifted to less developed or developing countries, where wages are measurably lower (Akrami, 2008:36). Foreign direct investments in China, which started in the early 1990s and gained momentum especially in the 2000s, should be evaluated in light of this background. In 2010, China reported 455.244 foreign-invested enterprises, which provided employment to 55.2 million workers in China (Congressional Research Service, 2019:14). Given the labour stock values, which show that China will likely continue to achieve labour-intensive growth, China can be expected to maintain its current growth model. Given that the rural labour stock is $44.4 \%$ as of 2015 , it is possible for China to maintain its own labour-driven growth model (Nişanc1 et al., 2017:343). However, increasing costs of urban living demonstrate that the labour-based growth model is not at a level that can be met by the labour force provided by the countryside. In other words, the wage level in China has been increasing recently. This means that China is losing its appeal of being the world's labour-intensive production centre. Conversely, China has also increased its foreign direct investments in recent years, particularly in Africa. These investments are examples of what is called South-South FDI. The terms "North" and "South" in this context are used in the literature to often denote "developed" and "developing" countries respectively (Aykut and Ratha, 2004:151). Thus, South-South FDI refers to investments by a developing country in another developing country. From a different perspective, China's investment policies in Africa have also been 
called "chopsticks mercantilism", although China states that these investments are based on a win-win principle and also contribute to the development of the African states.

Based on this situation, the motivation of the present study stems from researching and evaluating the fundamentals of Chinese investment policy in Africa, which has increased in volume in recent years. Therefore, the present study aims to answer the following questions and to evaluate the policies implemented accordingly: Are Chinese FDI in Africa supported by normative economic and institutional pull factors that regularly attract investments? Or rather, are the increasing investments by China in the region the result of neo-mercantilist policies? To this end, we will first explain the theoretical framework of FDI. Afterwards, we will evaluate China's growth process and the development of its FDI policies in African states within this process. Then, we will assess China's economic presence in Africa over this period. After outlining and explaining the data and the econometric methodology, we will finally present and discuss our findings.

\section{Pull and Push Factors for South-South FDI}

The pull factors of FDI in the Chinese-African case can be evaluated in terms of SouthSouth Cooperation (SSC). Although there are different definitions, the UN defines SSC as a "process where two or more countries pursue their individual and/or national capacity development objectives through exchanges of knowledge, skills, resources and technical know-how, and through regional and interregional collective actions, including partnership involving governments, regional organizations, civil society, academia and the private sector, for their individual and/or mutual benefit within and across regions" (UNDP, 2016:9). It is also stated that SSC is not a substitute for, but rather a complement to NorthSouth cooperation. However, SSC does not cover only grants and technical cooperation, but also trade, investments, regional economic integration, remittances, etc. (Besherati and MacFeely, 2019:6). For this reason, Chinese FDI in African countries are most robustly evaluated within this broader context.

It is reported that although SSC is not a new phenomenon on the African continent, the content of this cooperation has shifted from political issues to economic issues since the late 1950s. Cooperation between Africa and the South is classified into three types (UNCTAD, 2010:2). The first type is bilateral cooperation between African countries and a developing country in another region. The second type is trilateral cooperation between an African country and two developing countries in distinct regions. The third type is regional cooperation between Africa as a whole and other developing regions. In this framework, the relations between China and Africa are classified in the first type of cooperation (UNCTAD, 2010:2).

Chinese economic activities in Africa are known to result in an overall increase in trade, aid and FDI (Busse et al., 2014:1). Within the scope of SSC, Chinese FDI 
in Africa are evaluated as South-South FDI. The motivation of this FDI is stated to be similar to those between developed and developing countries (North-South FDI). In other words, the same push and pull factors, structural, cyclical and policy factors are equally valid in South-South FDI (UNCTAD Secretariat, 2005:1). According to Aykut and Ratha (2004:168-170) there are some important push and pull factors to consider in these situations. Within the liberalization era, rising wealth in some emerging economies increased the supply of capital in these economies, and soon companies in these emerging economies directed their investments to other developing economies in a search for higher returns and lower risks. Trans-national companies (TNC) had also limited market growth opportunities in the domestic economy and invested in other developing economies for market-seeking ventures. Another push factor was the need to enhance export competitiveness and to defend export markets after increased competition. In other words, this push factor was based on efficiency-seeking intentions. An additional push factor for TNC in emerging economies was their resource-seeking. That is to say, increasing demand for raw materials and energy resources encouraged these emerging countries to invest in other developing countries.

Essential pull factors in developing economies are understood to be low labour costs, investment incentives, market access to both domestic and export markets, capital account liberalization and financial deregulation. In addition to these, some other pull factors are said to exist for South-South FDI such as ethnic and cultural ties and geographic proximity. These additional factors stem from the high costs of obtaining reliable information about foreign markets for relatively small TNC from the South. For some of these reasons, these types of TNC prefer to invest in neighbouring countries where they have a level of familiarity with their ethnic, cultural or economic way of life (Aykut and Ratha, 2004:168-170). Additionally, institutional quality is stated to be another important factor of South-South FDI (Asian Development Bank, 2011:73). North's (1991) definition of "institution" is given as the "constraints that structure political, economic and social interactions and that are created by human beings". These institutions could be manifested in formal structures like property rights, laws and constitutions as well as informal structures such as taboos, customs, endorsements and ethics. North emphasizes that the fundamental problem of economic development and economic history is to explain the evolution of political and economic institutions that could create an economic environment that would stimulate an increase in productivity (North, 1991). Furthermore, Kaufmann et al. (2010) describe six different indicators with extensive details covering economic and political institutions: political stability, government efficiency, voice and accountability, rule of law, regulatory quality and control of corruption. There are a vast number of empirical studies that indicate these structural indicators are quite important pull factors for host countries to attract FDI. 


\section{Growth Path and FDI in China}

Considering China's traditional development model based on investment and export, it is observed that investments were covered by national savings at the beginning and that foreign investments began to increase significantly after 1978. Later, the interest of foreign investment in China continued to increase and in 2003 China became the world's largest foreign investment recipient. Undoubtedly, the willingness of foreign capital to invest in China has been influenced by the desire to benefit from cheap labour, to produce at low costs and to export to world markets (Savaş, 2016). In line with these developments, the fact that China became a member of the World Trade Organization in 2001 made the country an important global player. The country has become an important producer and exporter in the global economy, and its need for energy has increased considerably. Both the openness of trade channels for increased production and the provision of energy security in order to meet the increasing energy need have become high-priority issues for Chinese administration (Balc1, 2018:2). These priorities have led the country to implement mercantilist policies.

The effects of energy on China's foreign policy was particularly felt after 1990. It has been noted that China attaches special importance to the Middle East, Africa and Latin America in providing energy security and increasing energy outputs, given the rise in its global performance (Atagenç, 2012:142-143). It is stated that the policies implemented by China in these regions are generally called energy mercantilism. In this process, there are three organizations directing China's energy policy: China National Petroleum Corporation (CNPC), China Petroleum and Chemical Corporation (SINOPEC) and China National Offshore Oil Corporation (CNOOC). In the early 1990s, China adopted a law amendment to support the cooperation of its national oil companies with non-Chinese firms. As a result, the outward orientation of Chinese state oil companies began and has continued (Ziegler and Menon, 2014:27). As will be discussed in the following sections, these external orientations and partnerships are policies that China applies to varying degrees, but are often criticized in African countries. The Chinese economy experienced a period of development and growth that gained momentum after 1978 and has become the second largest economy in the world, the largest exporter and the country that attracts the most foreign direct investments. This acceleration of growth was largely achieved by low-cost investments, cheap labour and abundance of natural resources. However, there has been a downward trend in China's two-digit growth rates in recent years. China reached its highest growth rate in 2007 with $14.2 \%$ and this rate was followed by a declining trend in the years after that. The growth rate continues to decline at present (World Bank, 2019a). The President of China announced at the Chinese National People's Congress that the expected growth rate in 2019 would be in the range of 6-6.5\%. This has represented the lowest growth rate since 1991 (Bloomberg HT). 
Following this slowdown in growth, China announced the objectives and outlines of a new development model in its Thirteenth Five-Year Plan in 2013. The aim of this model, which is called the "new normal", is defined as achieving low but sustainable growth. The main objectives adopted in this new model are a growth rate of up to $5 \%$ in the $2020 \mathrm{~s}$, a steady increase in average income and the reduction of inequalities through restructuring the country's production system. In order to achieve these goals, a production structure will be created that covers domestic demand, innovative industries and backward regions (Aglietta and Bai, 2016:2-3).

China, which is described as the "factory of the world", is losing its competitive advantage of cheap labour. Other important issues to be addressed in this process are the subsequent rise in wages in China and the foreign direct investments made by China abroad. China's power, after a technological development and maturation process, is now shifting from a low-cost manufacturing centre to high-tech and service sectors (FDI China, 2019). A report of the German Chamber of Commerce in China stated that China increased its global labour supply when it became a member of the World Trade Organization, but this surplus of labour had decreased in recent years and the country's transition to a higher value-added production model was effective in this decrease. As a result, it has been stated that wages have started to rise in China, and some provinces have even approached the wage levels in some European regions (German Chamber of Commerce in China, 2018:12).

The annual wage level in the manufacturing sector in China has been increasing from year to year. When the wage data are analysed (Trading Economics, 2019), the findings show that average wages increased by $134 \%$ in the period from 2010 to 2018. According to World Bank data, China's consumer price index increased by $21.6 \%$ in the same period (World Bank, 2019b). This increase shows that wages have increased in real terms and that this real wage increase has negatively affected China's competitive production structure based on cheap labour. Consequently, an understanding of China's foreign direct investments in Africa should be approached in this respect. Therefore, China-Africa cooperation is also of interest to Chinese investors due to China's "new normal" development plan and its policies and the potential it has to influence the dynamic of the China-Africa cooperation.

\section{Relation Between the Existence of China in Africa and "Chopsticks" Mercantilism}

Investments are considered the engine of China-Africa economic and trade cooperation, and many mechanisms and programmes have been established to strengthen it. In this context, Chinese investments in Africa have increased significantly in recent years. 


\section{Figure 1: Chinese and US foreign direct investment flows to Africa}

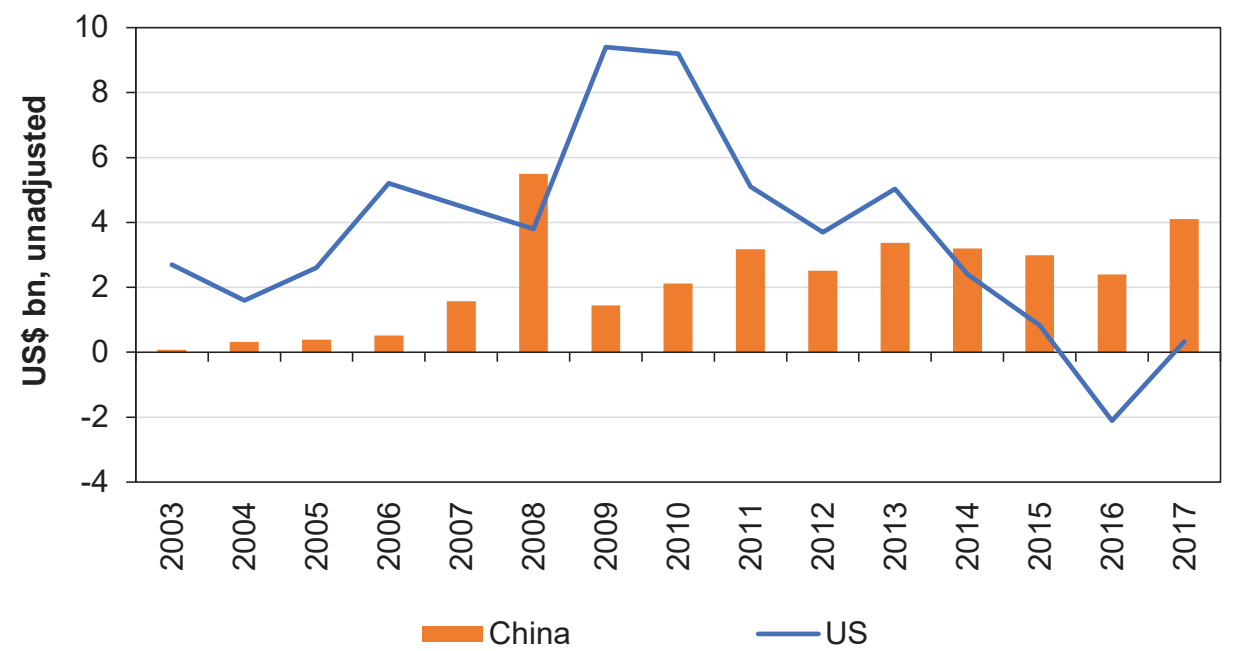

Source: China-Africa Research Initiative (2019)

In Figure 1, which presents the foreign direct investments of China and the US in Africa comparatively, it is seen that the flow of foreign direct investments from the US to Africa started to decrease in 2009. However, Chinese foreign direct investment flow, which had been weak before 2006, has increased since that year.

China's presence in Africa is considered to be different from the policies previously implemented by Western countries. The major factor in this difference is that China is engaged in activities to improve the region's infrastructure. Improving road and rail infrastructure in Nigeria, improvement of railways and construction of a new airport and refinery project in Angola, a bridge project between Zambia and the Democratic Republic of Congo, investments in Sudan which include refineries, roads, railways, hydroelectric power plants and gold mines are some of these projects (Gonzales Vicente, 2011:71). As can be seen from the distribution of investments in Table 1, China's connections in Africa aim especially to access natural resources, to help find a market for goods produced in China and to improve manufacturing activities by taking advantage of the low labour costs on the continent. On the other hand, it is stated that China's investments in Africa have not provided the expected improvement in issues such as creating qualified jobs and improving manufacturing technology and that its involvement creates a business environment that generates corruption and environmental pollution by undermining domestic industries (Scobell et al., 2018:187-188). 
Table 1: Top five sectors in Africa with the highest share of Chinese FDI (\%)

\begin{tabular}{l|c|c|c|c|c}
\hline Years & Construction & Mining & Manufacturing & $\begin{array}{c}\text { Financial } \\
\text { intermediation }\end{array}$ & $\begin{array}{c}\text { Computer } \\
\text { science and } \\
\text { software }\end{array}$ \\
\hline $\mathbf{2 0 1 3}$ & 26.1 & 26.4 & 13.4 & 14 & 5.1 \\
\hline $\mathbf{2 0 1 4}$ & 24.7 & 24.5 & 13.6 & 16.4 & 4.2 \\
\hline $\mathbf{2 0 1 5}$ & 27.4 & 27.5 & 13.3 & 9.9 & 4.2 \\
\hline $\mathbf{2 0 1 6}$ & 28.3 & 26.1 & 12.8 & 11.4 & 4.8 \\
\hline $\mathbf{2 0 1 7}$ & 29.8 & 22.5 & 14 & 13.2 & 5.3 \\
\hline
\end{tabular}

Source: China-Africa Research Initiative (2019)

Table 1 shows the top five sectors in which China's foreign direct investments are the highest in Africa. The construction and mining sectors have the highest share with approximate values. On the other hand, the share of the manufacturing sector in total foreign direct investments in the region is low. This can be interpreted with the understanding that China is engaged in supplying raw materials and creating the infrastructure to carry these raw materials, rather than productive activities.

According to Zhang and Kangombe (2016:70), the motive behind Chinese multinational companies' investments in Africa can be analysed in four main categories: (i) market-seeking, (ii) efficiency-seeking, (iii) resource-seeking, and (iv) strategic asset seeking. The motivation for seeking strategic assets is encountered when seeking new technology or an effort to increase productivity, and this motivation is decisive in investments in industrialized countries. Therefore, the motive of strategic asset seeking is not the way to understand China's investments in Africa. Zhang and Kangombe argue that investments based on efficiency-seeking are the basis of investments made in electrical and electronic products and in information technology products, and that this motive is not a determining factor in the African investments of Chinese companies (Zhang and Kangombe, 2016:70). The remaining two motives, namely market-seeking and resource-seeking, form the basis for China's investments in Africa. It is possible to say that the investments made with these motives also serve neo-mercantilist practices.

Table 2 shows the total shares of African countries in the world's natural resource production for the years 2000 and 2010. Depending on these shares, it can be stated that African countries have an important share in world production, especially in terms of mining. 
Table 2: Share of Africa in natural resource production in the world

\begin{tabular}{l|c|c}
\hline Type of natural resource & $\mathbf{2 0 0 0}$ & $\mathbf{2 0 1 0}$ \\
\hline Platinum group minerals & 55 & 74 \\
\hline Cobalt & 43 & 62 \\
\hline Diamonds & 45 & 54 \\
\hline Chromite & 51 & 42 \\
\hline Manganese & 32 & 30 \\
\hline Phosphates & 28 & 26 \\
\hline Gold & 24 & 19 \\
\hline Uranium & 17 & 19 \\
\hline Copper & 3 & 8 \\
\hline Nickel & 5 & 5 \\
\hline Iron ore & 5 & 4 \\
\hline Mining total & 14 & 12 \\
\hline Oil & 10 & 11 \\
\hline Gas & 5 & 7 \\
\hline Coal & 6 & 4 \\
\hline Energy total & 10 & 11 \\
\hline
\end{tabular}

Source: African Development Bank Group (2016), "Catalyzing growth and development through effective natural resources management".

China's neo-mercantilist policies in Africa, which have a special importance in terms of energy demand, are called "chopsticks mercantilism". The reason behind the use of the term "chopsticks", which is the name given to the sticks used by the Chinese to eat, is that China selects African countries to invest based on their natural resources with the same dexterity needed in using chopsticks. Some examples are that China chose Zimbabwe for platinum, Zambia for copper and Angola, Nigeria and Sudan for oil. Rene N'Guetta Kouassi, the head of the economic relations department of the African Union, pointed out that Africa should not jump blindly from neo-colonialism to a new Chinesetype neo-colonialism (Pambazuka News, 2019).

On the other hand, China states that the cooperation is based on a "win-win" approach. In fact, it is also acknowledged that investments in Africa within the framework of cooperation such as road and railway construction, ports, pipelines, mines, etc., 
can-not be made without Chinese support. However, the policy pursued by China within the framework of cooperation raises doubts, because China enters into partnerships and holds high shares in its investments. For example; $90 \%$ of the uranium mine in Namibia is owned by the China General Nuclear Power Group and $10 \%$ is owned by the Namibian government (New York Times, 2019). In addition, there is criticism that China, which receives resources from African countries in return for its investments in these countries, inflates its estimated costs of infrastructure investments and uses these investments as a means of exploitation of the region's resources (Al Mariam, 2019).

In the light of these explanations, the aim of this study is to analyse whether the factors that generate China's foreign direct investments in the region produce this mechanism in accordance with what is expected in theory. Before explaining the research and findings of the present study, papers focused on FDI in African countries are summarized in the following section.

\section{Literature Review}

Although FDI into African countries interest economists, papers investigating the determinants that pull the FDI and the impact of these FDI on African countries are quite new in the literature. The main reason for this is the lack of availability of data related to African countries. In this part of the study, we present a summary of these limited papers based on the determinants of the FDI in Africa. We separate these studies into two groups. Those in the first group focus on general FDI in Africa, while those in the second group focus on the FDI from China. The studies in this latter group are naturally directly related to our study. However, the studies investigating the determinants of FDI coming into Africa from all over the world also have important connections to our work.

In one of the papers in the first group, Sichei and Kinyondo (2012) analysed the factors that determine the FDI in 45 African countries between 1980 and 2009. The authors used agglomeration economies, natural resources, real GDP and international investment agreements as explanatory variables. The findings reveal that agglomeration economies are the variable that has the greatest impact on FDI in Africa. They also found that real GDP and the existence of natural resources also have a positive impact on FDI. Adinda (2018) investigated FDI in 33 African countries as a function of variables such as market size, openness, economic stability and agglomeration between 2008 and 2016. As a result of the analysis of various regression functions, the author revealed a positive relationship between market size and FDI. According to the results, agglomeration force (urban population) also has a positive impact on FDI. The author also investigated whether the regions of the continent affect the FDI inflows in Africa and revealed that Southern Africa has a positive impact on attracting investments. Yakubu et al. (2019) analysed 
the determinants of FDI in the agriculture, service and manufacturing sectors in 45 African countries for the period 2000-2015. The results indicated that the determinant variables differ for each sector. Accordingly, the determinants of FDI in the agriculture sector are market size and labour costs while the determinants of FDI in the service sector are trade openness and exchange rate. However, the authors have not found any significant determinant of FDI in the manufacturing sector.

When it comes to the type of papers that we described as the second group, there is again a small number of empirical studies. In one of them, Claassen et al. (2011) analysed the properties of Chinese FDI and their impact on 45 African countries in the period 2003-2008. Their findings indicated that agricultural land, market size and existence of oil are the determinants of Chinese FDI. Another finding of the study revealed that Chinese FDI in these countries have a positive impact on their GDP. The authors also investigated causal relations between Chinese FDI and the explanatory variables. As a result of the causality analysis, they found a bi-directional causal relationship between Chinese FDI and African GDP. The authors also revealed that there is a uni-directional relationship from corruption to Chinese FDI, and they interpreted the results of their research to show that corruption facilitates Chinese firms' investment in Africa. A bi-directional causal relationship between human capital and Chinese FDI is another finding of the study. In a more focused study, Kokouma and $\mathrm{Xu}$ (2013) analysed the determinants of the Chinese FDI in Guinea from 2006 to 2010. Market size, the employment ratio of the population aged 15-24, economic growth and trade openness are used as explanatory variables. Their findings indicated that China's increasing interest in the country is related to its increasing trade and economic cooperation with China. Breivik (2014) examined the impact of GDP, trade openness, institutions, natural resources, inflation, interactions between institutions and natural resources on Chinese FDI in 49 African countries between 2003 and 2011. The findings indicated that Chinese FDI prefer countries with a large market size and natural resources. In this sense, the author revealed that China invests in Africa with the same purposes, namely market-seeking and resource-seeking, as other countries. The study did not confirm that Chinese FDI are directed to countries with characteristics such as natural resource abundance on the one hand and weak institutions on the other. Rather, the results revealed that the existence of natural resources and qualifying institutions have been more effective interactively to pull Chinese FDI. Ross et al. (2019) examined the impact of institutional quality related to the host countries on Chinese FDI. The authors used GDP growth, inflation rate, GDP per person employed and total natural resource rents as economic indicators, while they used control of corruption, political stability and absence of violence, regulatory quality, rule of law and voice and accountability as institutional quality indicators. The analysis covered Nigeria, Zambia, Algeria, South 
Africa, Ghana, Sudan, Egypt and Kenya for the period 2003-2015. The findings revealed that institutional environment in the host country has a positive impact on Chinese FDI. Moreover, there has been a shift in terms of the aims of these investments from efficiencyseeking to resource-seeking. The findings also indicated that macroeconomic stability has a significant positive impact on Chinese FDI in Africa.

\section{Hypothesis and Data}

As discussed in the previous sections, Africa has been an area where China's infrastructurebased investments have increased, especially since the mid-2000s. Therefore, did the factors that drive these investments act in accordance with the theory? In other words, have the economic and institutional factors that historically and theoretically attract foreign direct investments truly affected Chinese foreign direct investments in Africa? In order to answer this question, ten African economies (South Africa, Democratic Republic of Congo, Zambia, Nigeria, Angola, Algeria, Zimbabwe, Ghana, Kenya and Tanzania) are examined in our study between 2003 and 2017. The reason why the analysis period is limited to 15 years is the lack of bilateral foreign direct investment data that are available. Regarding the selection of countries, the top ten countries with the highest share in China's foreign direct investment stock of Africa in 2017 were taken into consideration. Although Ethiopia ranks sixth with a $4.56 \%$ share, it is excluded from the analysis due to a lack of data.

Table 3: Top ten African countries in China's foreign direct investment stock in 2017

\begin{tabular}{l|c}
\hline Country & $\%$ \\
\hline South Africa & 17.26 \\
\hline Democratic Republic of Congo & 8.97 \\
\hline Zambia & 6.84 \\
\hline Nigeria & 6.61 \\
\hline Angola & 5.22 \\
\hline Algeria & 4.24 \\
\hline Zimbabwe & 4.04 \\
\hline Ghana & 3.64 \\
\hline Kenya & 3.56 \\
\hline Tanzania & 2.96 \\
\hline
\end{tabular}

Source: China-Africa Research Initiative (2019) 
The ten countries in Table 3 account for approximately $63 \%$ of China's foreign direct investment stock in Africa in 2017.

Figure 2: Foreign direct investment stock from China (Log FDI, 2003-2017)

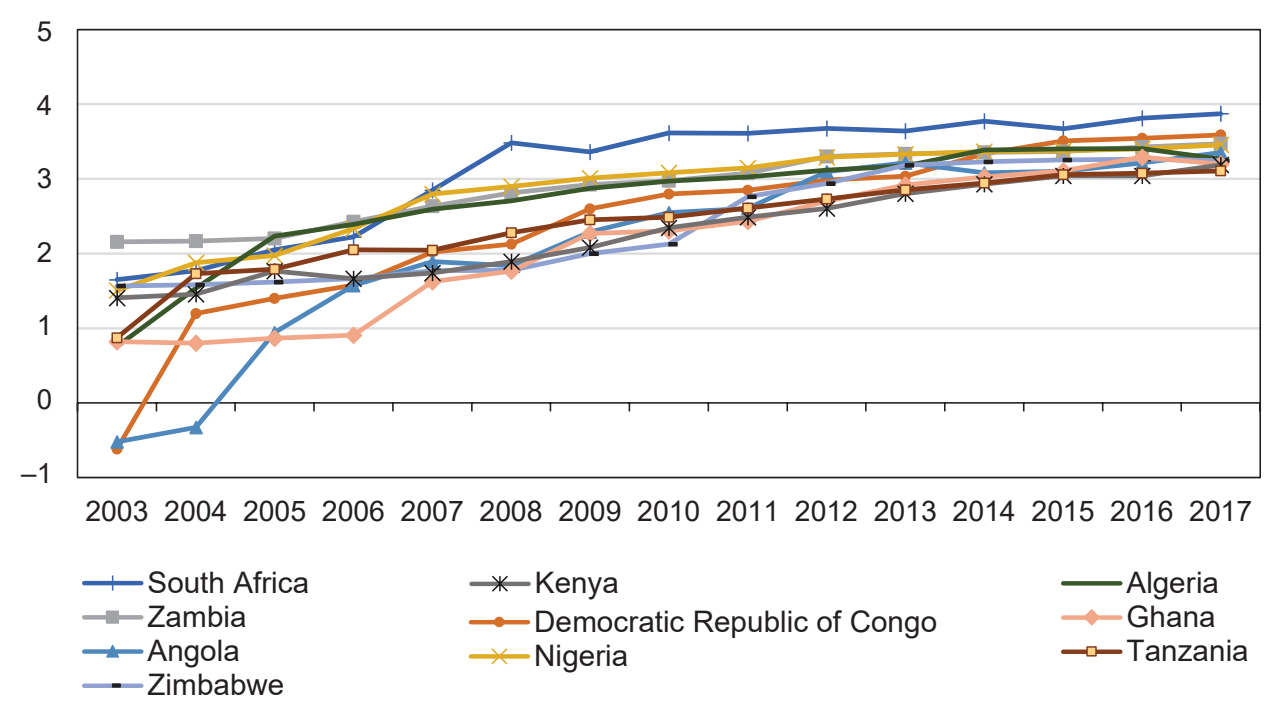

Source: China-Africa Research Initiative (2019), authors' drawing

The trend of the foreign direct investment stock from China to these countries in the period 2003-2017 is shown in Figure 2. As can be seen in the figure, South Africa has exhibited significant variation in terms of FDI stock from other countries since 2007. After years of racism, South Africa attempted to completely reorganize its governance system with the advent of democracy in 1994. Within the framework of the new democracy led by Mandela, a unitary but decentralized state structure was adopted, and the administration is now organized on three levels: national, provincial and local. The Constitution was based on a cooperative management between these three layers (Feinstein, 2015:1). The main stated purpose of the decentralization policy supported by the 1996 Constitution was to close the gap between democratic institutions and the population (KAS SouthAfrica Office, n.d.:1). The 1994 elections were declared to be the first multiracial election and the Constitution was described as one of the most progressive ones. However, under the surface, Lieberman et al. (2017) describes South Africa as a country in which there are serious accountability and political performance problems and the news and media continue to report the existence of major corruption issues (Lieberman et al., 2017:6). 
For these reasons, it is quite peculiar that South Africa would pull such sizable foreign direct investments from China. The same features that exist in South Africa also exist in the other countries in the region. Nevertheless, in general, it is observed that there is an increase in foreign direct investment stock in all the ten countries.

The theoretical studies show that there are three types of variables in the models aimed at explaining foreign direct investments. These are market-related variables, distance-related variables, and factor endowment-related variables (Borrmann et al., 2005:4-5). Market-related variables are the GDP of the host country receiving investment, which represents its market volume, the level of development, which represents the demand differentiation, the population of the host country, representing country size, and the GDP of the neighbouring countries, representing the market potential beyond the host country's market. Distance-related variables are the geographical distance between the capitals or economic centres of the countries and the factors that may affect the economic distance between countries such as a common border, openness to imports, common language or economic and political risk in the host country. Variables related to the factor endowment of the countries are variables such as capabilities of the labour force in the host country, the wage level in the host country and the per capita GDP as an indicator of the level of general and technological development.

In this study, GDP, which represents the economic volume of the host country, is used as a market-related variable. The trade openness indicator (Trade/GDP $\times 100$ ), which is also a market-related variable, was used as an indicator of the extent to which countries are integrated into the global economy. The share of total natural resource rents in GDP, which is used as an important indicator for building an analytical framework for sustainable development of an economy, was also used in the analysis. Competitive forces expand supply for produced goods and services, until economic profits are driven to zero. However, natural resources give rise to economic rents (revenues above the costs of extracting the resources) since these natural resources are not produced. Earnings from natural resources account for a sizable share of GDP in some countries and many of these earnings are in the form of economic rents (World Bank, 2020). In the present study, we aim to examine whether natural resource rents in African countries attract Chinese FDI by using this variable. In addition, a number of institutional indicators have been used which are determinative of economic distance between countries. These indicators are the rule of law index, the voice and accountability index, the control of corruption index and the regulatory quality index released by the World Bank. In Table 4, the variables used in the study, their definition and the data sources are presented in detail. 
Table 4: Variables and data sources

\begin{tabular}{l|l|l}
\hline Variable & \multicolumn{1}{|c}{ Definition } & \multicolumn{1}{c}{ Data source } \\
\hline LogFDI & $\begin{array}{l}\text { Logarithm of the stock of foreign direct investment } \\
\text { by China in African countries }\end{array}$ & $\begin{array}{l}\text { China-Africa Research } \\
\text { Initiative (John Hopkins } \\
\text { School of Advanced } \\
\text { International Studies) }\end{array}$ \\
\hline LogGDP & Logarithm of GDPs of African countries & World Bank \\
\hline LogOpenness & $\begin{array}{l}\text { Logarithm of trade openness, which is the ratio of total } \\
\text { imports and exports of African countries to GDP }\end{array}$ & World Bank \\
\hline $\boldsymbol{V A}$ & $\begin{array}{l}\text { Logarithm of the share of total natural resource rents } \\
\text { in GDP }\end{array}$ & World Bank \\
\hline $\boldsymbol{C C}$ & Voice and accountability indices of African countries & World Bank \\
\hline $\boldsymbol{R} \boldsymbol{R}$ & Control of corruption indices of African countries & World Bank \\
\hline
\end{tabular}

Source: Authors' calculations

Descriptive statistics of the variables are shown in Table 5. According to this, the average values for the $\log F D I, \log G D P, \log$ Openness, and $\log$ Resources variables reflect averages of logarithmic values. The index variables $V A, C C, R L$ and $R Q$ used in the model lie in the range from -2.5 to 2.5 . Convergence to -2.5 means deterioration in the indicator, while convergence to 2.5 means improvement (World Bank, 2019c). The average value of the $V A$ variable for these countries in the period 2003-2017 is -0.523 . The lowest value of this variable is -1.697 , which belongs to the Democratic Republic of the Congo, the highest value is 0.716 for South Africa. The average value of the $C C$ variable is -0.77 . The lowest value of $C C$ is -1.525 , belonging to the Democratic Republic of the Congo, the highest value is 0.568 for South Africa. The lowest and the highest values of the $R L$, in which the average value is -0.787 , belong to Zimbabwe and South Africa respectively. When it comes to $R Q$, in which the average value is -0.704 , the lowest and the highest values of this variable belong again to Zimbabwe and South Africa respectively. While the index with the lowest average value for these ten African countries is $R L$, the index with the highest average value is $V A$. The standard deviation values of the variables are also low, meaning that the variability and deviation from the average is low. 
Table 5: Descriptive statistics

\begin{tabular}{l|c|c|c|c|c}
\hline Variable & $\begin{array}{c}\text { Number } \\
\text { of observations }\end{array}$ & Mean & $\begin{array}{c}\text { Standard } \\
\text { deviation }\end{array}$ & Minimum & Maximum \\
\hline Log FDI & 150 & 2.539 & 0.871 & -0.620 & 3.873 \\
\hline Log GDP & 150 & 5.107 & 0.497 & 4.262 & 6.013 \\
\hline Log Openness & 150 & 1.783 & 0.143 & 1.316 & 2.088 \\
\hline Log Resources & 150 & 1.089 & 0.331 & 0.394 & 1.753 \\
\hline $\boldsymbol{V A}$ & 150 & -0.523 & 0.697 & -1.697 & 0.716 \\
\hline $\boldsymbol{C C}$ & 150 & -0.770 & 0.531 & -1.525 & 0.568 \\
\hline $\boldsymbol{R L}$ & 150 & -0.787 & 0.612 & -1.852 & 0.255 \\
\hline $\boldsymbol{R Q}$ & 150 & -0.704 & 0.684 & -2.236 & 0.804 \\
\hline
\end{tabular}

Source: Authors' calculations

Table 6 shows the correlation matrix of the independent variables used in the study. The analysis of the correlation matrix prior to econometric analysis is important in order to prevent multicollinearity problems. Because multicollinearity may cause incorrect estimates of regression coefficients, increase confidence intervals and decrease t-test values. Although there are several ways to determine whether there is multicollinearity between the independent variables, one of them is the examination of the correlation coefficients. If the absolute value of the correlation coefficient between the variables approaches 1 , it is stated that there is multicollinearity between the variables (Topal et al., 2010:54).

Table 6: Correlation matrix

\begin{tabular}{l|c|c|c|c|c|c|c}
\hline & Log GDP & $\begin{array}{c}\text { Log } \\
\text { Openness }\end{array}$ & $\begin{array}{c}\text { Log } \\
\text { Resources }\end{array}$ & VA & CC & RL & RQ \\
\hline Log GDP & 1 & - & - & - & - & - & - \\
\hline Log Openness & -0.39 & 1 & - & - & - & - & - \\
\hline Log Resources & -0.06 & 0.52 & 1 & - & - & - & - \\
\hline $\boldsymbol{V A}$ & 0.32 & -0.17 & -0.51 & 1 & - & - & - \\
\hline $\boldsymbol{C C}$ & 0.31 & -0.02 & -0.28 & 0.88 & 1 & - & - \\
\hline $\boldsymbol{R L}$ & 0.32 & -0.11 & -0.38 & 0.94 & 0.93 & 1 & - \\
\hline $\boldsymbol{R Q}$ & 0.42 & -0.16 & -0.43 & 0.93 & 0.82 & 0.90 & 1 \\
\hline
\end{tabular}

Source: Authors' calculations 
When Table 6 is examined, it is seen that the correlation coefficients between the variables $V A, C C, R L$ and $R Q$ are above 0.80 . In this case, inclusion of these variables in the model at the same time will cause multicollinearity problems. In order to avoid this, four different models are estimated in which each of these variables is included as an independent variable separately. These models are as follows:

$$
\begin{array}{r}
\operatorname{LogFDI}_{i t}=\alpha_{i}+\beta_{1 i}{\log G D P_{i t}+}_{2 i} \operatorname{LogOpenness}_{i t}+\beta_{3 i} \operatorname{LogResources}_{i t}+\beta_{4 i} V A_{i t}+\varepsilon_{i t} \\
(\text { Model 1) } \\
\operatorname{LogFDI}_{i t}=\alpha_{i}+\beta_{1 i} \operatorname{LogGDP}_{i t}+\beta_{2 i} \text { LogOpenness }_{i t}+\beta_{3 i} \text { LogResources }_{i t}+\beta_{4 i} C C_{i t}+\varepsilon_{i t}
\end{array}
$$

(Model 2)

$$
\log F D I_{i t}=\alpha_{i}+\beta_{1 i}{\log G D P_{i t}}+\beta_{2 i} \text { LogOpenness }_{i t}+\beta_{3 i} \text { LogResources }_{i t}+\beta_{4 i} R L_{i t}+\varepsilon_{i t}
$$

(Model 3)

$$
\operatorname{LogFDI}_{i t}=\alpha_{i}+\beta_{1 i}{\log G D P_{i t}}+\beta_{2 i} \text { LogOpenness }_{i t}+\beta_{3 i} \text { LogResources }_{i t}+\beta_{4 i} R Q_{i t}+\varepsilon_{i t}
$$

(Model 4)

In the equations, $i=1,2, \ldots, N$ represents the cross-section dimension, $t=1,2, \ldots$, $T$ represents the time dimension and $\varepsilon_{i t}$ represents the error term. The index data of the African countries could not be used in logarithmic form due to their negative value. The theoretical expected result of the forecast is that the variable of $G D P$, which represents the market size of the host country, will positively affect foreign direct investment. Trade openness shows that the host country has strong relations with the global economy, and is expected to have a positive impact on foreign direct investments. Natural resource rents indicate the share of economic rents in GDP that stem from the extraction of natural resources, and this is expected to have a positive impact on foreign direct investments. The indicators of voice and accountability, control of corruption, rule of law and regulatory quality are expected to have a positive impact on foreign direct investments. Before the findings, it will be useful to provide some information about the econometric method in the following section.

\section{Econometric Methodology}

The fact that the series used in the econometric analysis is stationary is important in order to avoid the spurious regression problem. Unit root tests used to determine stationarity in a panel data analysis are divided into two as first-generation tests and second-generation 
tests. First-generation tests assume that there is no cross-section dependence, while secondgeneration tests assume that there is a cross-section dependence (Yerdelen Tatoğlu, 2013:199). For this reason, cross-section dependence tests should be applied to the series before proceeding to regression estimation; then, according to the results of this test, the appropriate unit root test should be selected and applied.

In panel data analysis, the first of the various tests developed to investigate cross-section dependence in the series is the Lagrange Multiplier (LM) test developed by Breusch and Pagan. The test statistic $\left(C D L M_{1}\right)$ of this test, which is used when the time dimension (T) of the panel data is greater than the cross-section dimension $(\mathrm{N})$, is expressed in Equation 1 (Pesaran, 2004:4):

$$
C D L M_{1}=T \sum_{i=1}^{N-1} \sum_{j=i+1}^{N} \hat{\rho}_{i j}^{2}
$$

Breusch and Pagan indicated that the $\mathrm{CDLM}_{1}$ test statistic follows asymptotically the $\chi^{2}$ distribution, under the null hypothesis which states that there is no cross-section dependence. Since the applicability of this test is not appropriate when $N \rightarrow \infty$, Pesaran developed a new test that can be used when $N$ and $T$ have large values. The test statistic for this test $\left(C D L M_{2}\right)$ is a scaled version of $C D L M_{1}$ and is formulated in Equation 2 (Pesaran, 2004:5):

$$
C D L M_{2}=\sqrt{\frac{1}{N(N-1)}} \sum_{i=1}^{N-1} \sum_{j=i+1}^{N}\left(T \hat{\rho}_{i j}^{2}-1\right)
$$

Pan et al. then developed another test, which is a different version of the LM test. The test statistic of this test $\left(L M_{a d j}\right)$ is given in Equation 3 (Pan et al., 2015:449):

$$
L M_{a d j}=\sqrt{\left(\frac{2 T}{N(N-1)}\right)} \sum_{i=1}^{N-1} \sum_{j=i+1}^{N} \hat{\rho}_{i j} \frac{(T-k) \hat{\rho}_{i j}^{2}-\mu_{T i j}}{\sqrt{v_{T i j}^{2}}}
$$

In this study, cross-section dependence was determined in every series and the MADF (Multivariate Aggregated Dickey-Fuller) test, which is one of the second-generation unit root tests, was used. The MADF test is a unit root test developed by Taylor and Sarno. Taylor and Sarno used the following equation in Equation 4 (Taylor and Sarno, 1998:287):

$$
q_{i t}=\mu_{i}+\sum_{j=1}^{k} p_{i j} q_{i t-j}+u_{i t}
$$

It is assumed in the test that the error term is independent and that it has a normal distribution. Taylor and Sarno estimated Equation 4 by taking into account the simultaneous correlation 
between error terms. The null hypothesis is expressed as in Equation 5 for the $\mathrm{N}$ equation (Taylor and Sarno, 1998:287):

$$
H_{0}: \sum_{j=1}^{k} \rho_{i j}-1=0, \quad \forall i=1, \ldots, N
$$

The Wald test statistic obtained as a result of this test is also called MADF statistics. The SUR (Seemingly Unrelated Regression) method is used to estimate Equation 4 (Taylor and Sarno, 1998:287). In addition to the MADF unit root test, the Hadri-Kurozumi test, which is also a second-generation test, was applied to the variables. Hadri and Kurozumi propose a simple test for the null hypothesis of stationarity in heterogeneous panel data with cross-section dependence in the form of a common factor. The two test statistics developed by Hadri and Kurozumi are (Hadri and Kurozumi, 2012: 32):

$$
Z_{A}^{S P C}=\frac{1}{\hat{\sigma}_{i S P C^{T^{2}}}^{2}} \sum_{t=1}^{T}\left(S_{i t}^{w}\right)^{2} \text { and } Z_{A}^{L A}=\frac{1}{\hat{\sigma}_{i L A^{T^{2}}}^{2}} \sum_{t=1}^{T}\left(S_{i t}^{w}\right)^{2} .
$$

As an alternative to the fixed coefficient model in the panel data analysis, the random coefficient model is used, which applies stochastic specification for each cross-section. This model allows the coefficient vector to differ from cross-section to cross-section and/ or differ over time (Hsiao and Pesaran, 2004:3). Following Swamy (1970), the random coefficient model can be represented with the matrix notation as in Equation 6 (Poi, 2003:302):

$$
y_{i}=X_{i} \beta_{i}+\epsilon_{i}
$$

$\beta_{i}$ is the $k \times 1$ dimensional parameter vector specific to the cross-section $i$ and is associated with a common parameter vector $\beta$ (Poi, 2003:302):

$$
\beta_{i}=\beta+v_{i}
$$

In the model in Equation 6, it is assumed that the error terms are heteroskedastic and they have different variances for different micro units (Swamy, 1970:313). The $\beta$ parameter, including the constant parameter, varies from cross-section to cross-section. For Equation 7, $E\left(v_{i}\right)=0$ and $E\left(v_{i} v_{i}^{\prime}\right)=\Sigma$ holds and $v_{i}$ is called "heterogeneity bias" (Yerdelen Tatoğlu, 2013:44). Swamy (1970:319) states that it is necessary to test whether the $\beta_{i}$ parameter vectors are constant and all are equal, before estimating the model. Accordingly, the zero hypothesis to be tested is expressed in Equation 8: 


$$
H_{0}: \beta_{1}=\beta_{2}=\ldots=\beta_{n}=\beta
$$

The hypothesis $H_{0}^{\prime}$ indicates that the coefficient vectors are constant and the crosssections examined are homogeneous. If this null hypothesis is confirmed, it will be shown that a common relationship between variables for each cross-section can be predicted. Therefore, if the null hypothesis is accepted, the random coefficient model will not need to be estimated. If the hypothesis $H_{0}^{\prime}$ is rejected, it will not be possible to pool the data of each cross-section to estimate a single coefficient which represents the relationship between the variables (Swamy, 1970:319). The test statistic which belongs to the parameter constancy test that is developed by Swamy as a Hausman-type test is formulated as follows (Yerdelen Tatoğlu, 2013:49):

$$
\chi_{k(m-1)}^{2}=\sum_{i=1}^{m}\left(\widehat{\beta}_{i}-\overline{\beta^{*}}\right)^{\prime} \hat{V}_{i}^{-1}\left(\widehat{\beta}_{i}-\overline{\beta^{*}}\right)
$$

After these explanations regarding the econometric method used in the analysis, the findings obtained are presented in the following section.

\section{Empirical Results}

Firstly, the results of the cross-section dependence test of the variables used in the study are presented in Table 7. When the table is examined, it is seen that the probability value of each test result for all the variables is less than 0.05 and so, the null hypothesis which indicates that there is no cross-section dependence is rejected. In other words, there is correlation between cross-sections in every series, meaning that a shock that occurs in one of the countries in terms of one variable affects the other countries in terms of the variable in question.

It was explained in the econometric method section that the stationarity of the series is tested using second-generation unit root tests in the case of cross-sectional dependence. In this study, the MADF test, which is one of the second-generation unit root tests, was applied to the series. 
Table 7: Cross-section dependence test results

\begin{tabular}{l|c|c|c|c|c|c}
\hline \multirow{2}{*}{ Variable } & \multicolumn{2}{|c|}{ CDLM1 } & \multicolumn{2}{c|}{ CDLM2 } & \multicolumn{2}{c}{ Lmadj } \\
\cline { 2 - 7 } & $\begin{array}{c}\text { Test } \\
\text { statistics }\end{array}$ & $p$-value & $\begin{array}{c}\text { Test } \\
\text { statistics }\end{array}$ & $p$-value & $\begin{array}{c}\text { Test } \\
\text { statistics }\end{array}$ & $p$-value \\
\hline Log FDI & $580.5493^{*}$ & 0.000 & $55.39776^{*}$ & 0.000 & $55.04062^{*}$ & 0.000 \\
\hline Log GDP & $584.9386^{*}$ & 0.000 & $55.86044^{*}$ & 0.000 & $55.5033^{*}$ & 0.000 \\
\hline Log Openness & $161.0609^{*}$ & 0.000 & $11.1798^{*}$ & 0.000 & $10.82266^{*}$ & 0.000 \\
\hline Log Resources & $146.0006^{*}$ & 0.000 & $9.592303^{*}$ & 0.000 & $9.23516^{*}$ & 0.000 \\
\hline VA & $157.2599^{*}$ & 0.000 & $10.77914^{*}$ & 0.000 & $10.422^{*}$ & 0.000 \\
\hline CC & $104.3448^{*}$ & 0.000 & $5.201403^{*}$ & 0.000 & $4.84426^{*}$ & 0.000 \\
\hline$R Q$ & $164.6723^{*}$ & 0.000 & $11.56047^{*}$ & 0.000 & $11.20333^{*}$ & 0.000 \\
\hline
\end{tabular}

*represents the 0.01 significance level.

Source: Authors' calculation

According to the MADF unit root test results in Table 8, the test statistic is greater than the critical value for every series. In other words, every series is stationary at its level. The Hadri-Kurozumi test results also support stationarity of the series at level. Therefore, these variables can be subjected to a regression analysis with level values without differentiating. However, based on Figure 2, which makes us consider that the LogFDI variable is trend-stationary, we used the de-trended $\log F D I$ variable with the HodrickPrescott method.

In this study, the estimate of the regression model was carried out using a random coefficient panel regression method, which is developed by Swamy and is a heterogeneous panel estimation method. As stated in the econometric method section, before applying this estimation method, the parameter constancy test is applied to the model to be estimated. If the null hypothesis, which indicates that the coefficients of the cross-sections are homogeneous, is rejected, it will not be correct to estimate the data of the units by pooling and subsequently estimating the random coefficient panel regression model. 
Table 8: Unit-root test results

\begin{tabular}{l|c|c|c|c}
\hline \multicolumn{5}{c}{ MADF unit-root test } \\
\hline Variable & MADF statistics & Critical value (5\%) & AIC & BIC \\
\hline Log FDI & $365.098^{* *}(4)$ & 132.778 & -373.127 & -353.232 \\
\hline Log GDP & $1108.884^{* *}(1)$ & 72.726 & -1072.1 & -1059.32 \\
\hline Log Openness & $180.937^{* *}(4)$ & 132.778 & -547.215 & -527.32 \\
\hline Log Resources & $185.32^{* *}(3)$ & 105.367 & -560 & -540.603 \\
\hline $\boldsymbol{V A}$ & $185.167^{* *}(4)$ & 132.778 & -653.57 & -633.676 \\
\hline $\boldsymbol{C C}$ & $173.384^{* *}(4)$ & 132.778 & -623.331 & -603.436 \\
\hline $\boldsymbol{R L}$ & $157.886^{* *}(4)$ & 132.778 & -612.246 & -592.351 \\
\hline $\boldsymbol{R Q}$ & $434.142^{* *}(4)$ & 132.778 & -519.969 & -500.074 \\
\hline
\end{tabular}

\begin{tabular}{l|c|c|c|c}
\hline \multirow{3}{*}{ Variable } & \multicolumn{3}{|c}{ Codri-Kurozumi unit-root test } \\
\cline { 2 - 5 } & $Z_{A}^{S P C}$ & $Z_{A}^{L A}$ & $Z_{A}^{S P C}$ & $Z_{A}^{L A}$ \\
\hline \multirow{2}{*}{ Log FDI } & $-0.8726^{* *}$ & $-1.3284^{* *}$ & $-1.1278^{* *}$ & $-1.6584^{* *}$ \\
& {$[0.8086]$} & {$[0.9080]$} & {$[0.8703]$} & {$[0.9514]$} \\
\hline \multirow{2}{*}{ Log GDP } & $-2.2263^{* *}$ & $-1.6597^{* *}$ & $-0.2690^{* *}$ & 4.9015 \\
& {$[0.9870]$} & {$[0.9515]$} & {$[0.6060]$} & {$[0.0000]$} \\
\hline \multirow{2}{*}{ Log Openness } & $-0.5153^{* *}$ & $-0.3594^{* *}$ & $-1.6403^{* *}$ & $-1.9760^{* *}$ \\
\hline \multirow{2}{*}{ Log Natural } & {$[0.6968]$} & {$[0.6404]$} & {$[0.9495]$} & {$[0.9759]$} \\
\hline \multirow{2}{*}{ VA } & $-0.8049^{* *}$ & $0.0313^{* *}$ & $-1.7930^{* *}$ & $-0.2471^{* *}$ \\
\hline \multirow{2}{*}{ CC } & {$[0.7896]$} & {$[0.4875]$} & {$[0.9635]$} & {$[0.5976]$} \\
\hline \multirow{2}{*}{ RL } & $-2.1819^{* *}$ & $-1.5214^{* * *}$ & $-0.6534^{* *}$ & 3.4184 \\
& {$[0.9854]$} & {$[0.9359]$} & {$[0.7433]$} & {$[0.0003]$} \\
\hline RQ & $-1.2084^{* *}$ & $-1.0947^{* *}$ & $-0.5198^{* *}$ & $0.7121^{* *}$ \\
& {$[0.8866]$} & {$[0.8632]$} & {$[0.6984]$} & {$[0.2382]$} \\
\hline
\end{tabular}

Note: The maximum lag length was selected as 4 and the optimal lag length was determined according to the AIC and BIC criteria in the MADF test. The values in square brackets correspond to $p$-values. ** refers to the 0.05 significance level.

Source: Authors' calculations 
Table 9: Parameter constancy test results

\begin{tabular}{l|c}
\hline Model & $X^{2}$ \\
\hline Model 1 & $155.87^{*}$ \\
& $(0.000)$ \\
\hline \multirow{2}{*}{ Model 2 } & $130.73^{*}$ \\
& $(0.000)$ \\
\hline \multirow{2}{*}{ Model 3 } & $124.79^{*}$ \\
& $(0.000)$ \\
\hline \multirow{2}{*}{ Model 4 } & $131.74^{*}$ \\
& $(0.000)$ \\
\hline
\end{tabular}

${ }^{*}$ represents the 0.01 significance level.

Source: Authors' calculations

The result of the parameter constancy test that the $p$-value for each model is lower than 0,05 indicates that coefficient vectors of cross-sections are not homogeneous and that these coefficients cannot be estimated using pooled models. Depending on this result, it is not significant to interpret average coefficients obtained via estimation of pooled regression. That is why the results from the random coefficient panel regression estimate for each model are presented in the following part of the study.

When the results of Model 1 in Table 10 are examined, it is seen that $\beta_{1}$, which is the coefficient of the $\log G D P$ variable, is statistically significant and positive for Nigeria, Angola, Algeria, Zimbabwe and Kenya while it is negative for Ghana. In other words, the size of the economy in these countries (except Ghana) affects the Chinese foreign direct investments positively. When $\beta_{2}$, which is the coefficient of the LogOpenness variable, is examined, it is seen that trade openness affects Chinese foreign direct investments in a positive manner in Algeria, Kenya and Tanzania, but in a negative manner in Ghana. When the $\beta_{3}$, the coefficient of the LogResources variable, is examined, it is seen that natural resource rents affect Chinese foreign direct investments in a positive manner in South Africa, Kenya and Ghana, but in a negative manner in Tanzania. When we compare the coefficients of natural resource rents, it is seen that the highest coefficient belongs to Ghana, which is the country among top ten countries in terms of pulling Chinese FDI, although its GDP and trade openness have a negative impact on these FDI. Economic size, trade openness and natural resource rents are the indicators which are expected to affect the inflow of foreign direct investments positively. However, when $\beta_{4}$ is examined, which is the coefficient of the $V A$ variable, it is seen that this coefficient has 
a positive value in Zambia and Algeria, while it does not have a significantly positive effect in South Africa, where Chinese foreign direct investment stock has the highest share (Table 3). When this result is evaluated against the fact that the "voice and accountability" indicator has a decreasing value in South Africa during the period (Appendix 1), these huge investments from China cannot be evaluated as a rational decision in such an institutionally risky country.

Table 10: Random coefficient regression estimation results of Model 1

\begin{tabular}{|c|c|c|c|c|}
\hline Country & $\beta_{1}$ & $\beta_{2}$ & $\beta_{3}$ & $\boldsymbol{\beta}_{4}$ \\
\hline South Africa & $\begin{array}{l}0.215 \\
(0.656)\end{array}$ & $\begin{array}{l}-0.725 \\
(0.408)\end{array}$ & $\begin{array}{l}1.322^{*} \\
(0.000)\end{array}$ & $\begin{array}{l}-0.590 \\
(0.254)\end{array}$ \\
\hline $\begin{array}{l}\text { Democratic } \\
\text { Republic of Congo }\end{array}$ & $\begin{array}{l}0.224 \\
(0.672)\end{array}$ & $\begin{array}{c}0.987 \\
(0.306)\end{array}$ & $\begin{array}{l}-1.524 \\
(0.150)\end{array}$ & $\begin{array}{c}0.119 \\
(0.791)\end{array}$ \\
\hline Zambia & $\begin{array}{l}-0.100 \\
(0.655)\end{array}$ & $\begin{array}{l}-0.141 \\
(0.759)\end{array}$ & $\begin{array}{l}-0.097 \\
(0.632)\end{array}$ & $\begin{array}{l}0.480^{* *} \\
(0.046)\end{array}$ \\
\hline Nigeria & $\begin{array}{l}0.744^{* * *} \\
(0.066)\end{array}$ & $\begin{array}{c}0.263 \\
(0.608)\end{array}$ & $\begin{array}{c}0.062 \\
(0.875) \\
\end{array}$ & $\begin{array}{l}-0.403 \\
(0.226)\end{array}$ \\
\hline Angola & $\begin{array}{l}1.301^{* *} \\
(0.028)\end{array}$ & $\begin{array}{c}0.187 \\
(0.868)\end{array}$ & $\begin{array}{l}0.921 \\
(0.107)\end{array}$ & $\begin{array}{l}-0.158 \\
(0.672)\end{array}$ \\
\hline Algeria & $\begin{array}{l}2.389^{*} \\
(0.000)\end{array}$ & $\begin{array}{l}5.888^{*} \\
(0.000)\end{array}$ & $\begin{array}{c}0.017 \\
(0.960)\end{array}$ & $\begin{array}{l}1.052^{*} \\
(0.000)\end{array}$ \\
\hline Zimbabwe & $\begin{array}{l}1.570^{*} \\
(0.002)\end{array}$ & $\begin{array}{l}1.109 \\
(0.176) \\
\end{array}$ & $\begin{array}{l}-0.685 \\
(0.125)\end{array}$ & $\begin{array}{l}-0.477 \\
(0.243)\end{array}$ \\
\hline Ghana & $\begin{array}{l}-0.734^{* * *} \\
(0.087)\end{array}$ & $\begin{array}{l}-1.955^{* *} \\
(0.043)\end{array}$ & $\begin{array}{l}1.953^{*} \\
(0.002)\end{array}$ & $\begin{array}{l}0.063 \\
(0.873)\end{array}$ \\
\hline Kenya & $\begin{array}{l}0.896^{* *} \\
(0.011)\end{array}$ & $\begin{array}{l}1.097^{* *} \\
(0.014)\end{array}$ & $\begin{array}{c}0.689^{* * *} \\
(0.070)\end{array}$ & $\begin{array}{l}0.542 \\
(0.128)\end{array}$ \\
\hline Tanzania & $\begin{array}{l}0.271 \\
(0.451)\end{array}$ & $\begin{array}{l}1.608^{* *} \\
(0.018)\end{array}$ & $\begin{array}{c}-1.558^{* *} \\
(0.049)\end{array}$ & $\begin{array}{l}-0.023 \\
(0.956)\end{array}$ \\
\hline
\end{tabular}

${ }^{*},{ }^{* *}$ and ${ }^{* * *}$ represent the $0.01,0.05$ and 0.10 significance levels, respectively.

Source: Authors' calculations 
Table 11: Random coefficient regression estimation results of Model 2

\begin{tabular}{|c|c|c|c|c|}
\hline Country & $\beta_{1}$ & $\beta_{2}$ & $\beta_{3}$ & $\boldsymbol{\beta}_{4}$ \\
\hline South Africa & $\begin{array}{l}-0.100 \\
(0.797)\end{array}$ & $\begin{array}{l}-0.752 \\
(0.451)\end{array}$ & $\begin{array}{l}1.433^{*} \\
(0.000)\end{array}$ & $\begin{array}{l}-0.139 \\
(0.531)\end{array}$ \\
\hline $\begin{array}{l}\text { Democratic Republic } \\
\text { of Congo }\end{array}$ & $\begin{array}{c}0.263 \\
(0.516)\end{array}$ & $\begin{array}{c}0.954 \\
(0.298)\end{array}$ & $\begin{array}{l}-1.386 \\
(0.149)\end{array}$ & $\begin{array}{l}-0.224 \\
(0.611)\end{array}$ \\
\hline Zambia & $\begin{array}{l}-0.179 \\
(0.360)\end{array}$ & $\begin{array}{l}-0.451 \\
(0.309)\end{array}$ & $\begin{array}{l}-0.109 \\
(0.520)\end{array}$ & $\begin{array}{l}0.747^{*} \\
(0.002)\end{array}$ \\
\hline Nigeria & $\begin{array}{c}0.453 \\
(0.150)\end{array}$ & $\begin{array}{c}0.299 \\
(0.498)\end{array}$ & $\begin{array}{c}0.294 \\
(0.296)\end{array}$ & $\begin{array}{l}0.596^{* *} \\
(0.015)\end{array}$ \\
\hline Angola & $\begin{array}{l}1.304^{* *} \\
(0.015)\end{array}$ & $\begin{array}{c}0.378 \\
(0.715)\end{array}$ & $\begin{array}{c}0.609 \\
(0.221) \\
\end{array}$ & $\begin{array}{l}1.034^{*} \\
(0.008) \\
\end{array}$ \\
\hline Algeria & $\begin{array}{l}1.612^{*} \\
(0.002)\end{array}$ & $\begin{array}{l}3.837^{*} \\
(0.002)\end{array}$ & $\begin{array}{l}-0.142 \\
(0.732)\end{array}$ & $\begin{array}{l}0.868^{* *} \\
(0.048)\end{array}$ \\
\hline Zimbabwe & $\begin{array}{l}0.976^{* *} \\
(0.017)\end{array}$ & $\begin{array}{l}1.381^{* * *} \\
(0.070)\end{array}$ & $\begin{array}{l}-0.849^{* * *} \\
(0.074)\end{array}$ & $\begin{array}{l}-0.203 \\
(0.595)\end{array}$ \\
\hline Ghana & $\begin{array}{l}-0.643 \\
(0.154)\end{array}$ & $\begin{array}{c}-1.728^{* * * *} \\
(0.098)\end{array}$ & $\begin{array}{l}1.880^{*} \\
(0.005)\end{array}$ & $\begin{array}{c}0.172 \\
(0.635)\end{array}$ \\
\hline Kenya & $\begin{array}{l}0.837^{* *} \\
(0.027)\end{array}$ & $\begin{array}{l}1.072^{* *} \\
(0.031)\end{array}$ & $\begin{array}{c}0.352 \\
(0.349)\end{array}$ & $\begin{array}{c}0.369 \\
(0.246)\end{array}$ \\
\hline Tanzania & $\begin{array}{c}0.418 \\
(0.147)\end{array}$ & $\begin{array}{l}1.866^{*} \\
(0.001)\end{array}$ & $\begin{array}{c}-1.943^{*} \\
(0.006)\end{array}$ & $\begin{array}{l}0.385^{* * * *} \\
(0.066)\end{array}$ \\
\hline
\end{tabular}

The values in the brackets represent the $p$-values. ${ }^{* * *}$ and ${ }^{* * *}$ represent the $0.01,0.05$ and 0.10 significance levels, respectively.

Source: Authors' calculations

When the results of Model 2 in Table 11, in which the $C C$ variable is used as an institutional indicator, are examined, it is seen that $\beta_{1}$, which is the coefficient of the $\log G D P$ variable, is again statistically significant and positive for Angola, Algeria, Zimbabwe and Kenya. The LogOpenness variable has a negative impact on Chinese foreign direct investments in Ghana, while it has a positive impact in Algeria, Zimbabwe, Kenya and Tanzania. The LogResources variable has a positive impact on Chinese foreign direct investments in South Africa and Ghana, while it has a negative impact in Zimbabwe and Tanzania. Here, it is observable again that Ghana has the highest coefficient in terms of natural resource rents although its GDP and trade openness are not attractive to pull Chinese FDI. When $\beta_{4}$, which is the coefficient of $C C$, is examined, it is observed that this institutional indicator has a positive impact on Chinese foreign direct investments in Zambia, Nigeria, Angola, Algeria and Tanzania. However, it should be noted that 
this indicator does not have a significantly positive impact of Chinese FDI in South Africa again. It becomes remarkable when the huge investments from China especially in South Africa are taken into consideration.

Table 12: Random coefficient regression estimation results of Model 3

\begin{tabular}{|c|c|c|c|c|}
\hline Country & $\beta_{1}$ & $\boldsymbol{\beta}_{2}$ & $\boldsymbol{\beta}_{3}$ & $\boldsymbol{\beta}_{4}$ \\
\hline South Africa & $\begin{array}{c}0.297 \\
(0.443)\end{array}$ & $\begin{array}{l}-0.420 \\
(0.582) \\
\end{array}$ & $\begin{array}{l}1.390^{*} \\
(0.000)\end{array}$ & $\begin{array}{l}-0.089 \\
(0.825) \\
\end{array}$ \\
\hline $\begin{array}{l}\text { Democratic } \\
\text { Republic of Congo }\end{array}$ & $\begin{array}{c}0.227 \\
(0.659)\end{array}$ & $\begin{array}{c}0.916 \\
(0.287)\end{array}$ & $\begin{array}{l}-1.450 \\
(0.200)\end{array}$ & $\begin{array}{c}0.071 \\
(0.893)\end{array}$ \\
\hline Zambia & $\begin{array}{l}-0.330 \\
(0.333)\end{array}$ & $\begin{array}{c}0.114 \\
(0.812)\end{array}$ & $\begin{array}{c}0.307 \\
(0.258)\end{array}$ & $\begin{array}{l}0.398 \\
(0.297)\end{array}$ \\
\hline Nigeria & $\begin{array}{c}0.096 \\
(0.738)\end{array}$ & $\begin{array}{c}0.289 \\
(0.546)\end{array}$ & $\begin{array}{c}0.342 \\
(0.275)\end{array}$ & $\begin{array}{c}0.538^{* *} \\
(0.049)\end{array}$ \\
\hline Angola & $\begin{array}{c}0.215 \\
(0.613)\end{array}$ & $\begin{array}{l}-0.072 \\
(0.936)\end{array}$ & $\begin{array}{l}1.250^{* *} \\
(0.023)\end{array}$ & $\begin{array}{c}1.151^{* *} \\
(0.012)\end{array}$ \\
\hline Algeria & $\begin{array}{l}0.703^{* *} \\
(0.020)\end{array}$ & $\begin{array}{l}1.803^{* *} \\
(0.019)\end{array}$ & $\begin{array}{l}0.821^{* *} \\
(0.033)\end{array}$ & $\begin{array}{c}-1.350 * \\
(0.002)\end{array}$ \\
\hline Zimbabwe & $\begin{array}{l}1.147^{* *} \\
(0.019)\end{array}$ & $\begin{array}{l}1.320^{* * *} \\
(0.061)\end{array}$ & $\begin{array}{l}-0.731 \\
(0.103) \\
\end{array}$ & $\begin{array}{l}-0.062 \\
(0.830) \\
\end{array}$ \\
\hline Ghana & $\begin{array}{l}-0.678 \\
(0.106)\end{array}$ & $\begin{array}{c}-1.710^{* *} \\
(0.029)\end{array}$ & $\begin{array}{l}1.855^{*} \\
(0.002)\end{array}$ & $\begin{array}{c}0.117 \\
(0.723) \\
\end{array}$ \\
\hline Kenya & $\begin{array}{c}0.387 \\
(0.304)\end{array}$ & $\begin{array}{l}1.236^{*} \\
(0.005) \\
\end{array}$ & $\begin{array}{c}0.353 \\
(0.327) \\
\end{array}$ & $\begin{array}{c}0.308^{* *} \\
(0.036)\end{array}$ \\
\hline Tanzania & $\begin{array}{c}0.044 \\
(0.864)\end{array}$ & $\begin{array}{l}1.536^{*} \\
(0.004)\end{array}$ & $\begin{array}{c}-2.354^{*} \\
(0.001)\end{array}$ & $\begin{array}{l}-1.014^{* *} \\
(0.022)\end{array}$ \\
\hline
\end{tabular}

${ }^{*},{ }^{* *}$ and ${ }^{* * *}$ represent the $0.01,0.05$ and 0.10 significance levels, respectively.

Source: Authors' calculations

In Model 3, the $R L$ variable is included as an institutional indicator in order to analyse the impact of the level of "rule of law" for the countries that receive Chinese foreign direct investments. According to the results in Table 12, the GDP of Algeria and Zimbabwe has a positive effect on Chinese investments in these countries. When it comes to trade openness, this indicator also has a positive effect on Chinese foreign direct investments in Zimbabwe, Algeria, Kenya and Tanzania, while it has a negative impact in Ghana. When the $\beta_{3}$ coefficient is examined, it is observed that natural resource rents, as expected, have a significantly positive impact on Chinese foreign direct investments in South Africa, 
Angola, Algeria and Ghana, while they have a negative impact in Tanzania. It should be noted that Ghana has the highest coefficient in comparison with South Africa, Angola and Algeria. When the coefficients of the $R L$ variable are evaluated, it is observed that it has a positive effect on Chinese investments in Nigeria, Angola and Kenya, meaning that the recovery of the "rule of law" in these countries has an enhancing impact on the inflow of foreign direct investments from China. However, it has a negative impact in Algeria and Tanzania. When this is evaluated against Appendix 1, it is observed that deterioration in the "rule of law" in these countries has an enhancing impact on the inflow of foreign direct investments from China.

Table 13: Random coefficient regression estimation results of Model 4

\begin{tabular}{l|c|c|c|c}
\hline Country & $\boldsymbol{\beta}_{\mathbf{1}}$ & $\boldsymbol{\beta}_{\mathbf{2}}$ & $\boldsymbol{\beta}_{\mathbf{3}}$ & $\boldsymbol{\beta}_{\mathbf{4}}$ \\
\hline \multirow{2}{*}{ South Africa } & -1.680 & -0.140 & $1.405^{*}$ & -0.517 \\
& $(0.130)$ & $(0.866)$ & $(0.000)$ & $(0.140)$ \\
\hline Democratic Republic & 0.453 & 1.231 & $-1.796^{* * *}$ & -0.417 \\
of Congo & $(0.402)$ & $(0.217)$ & $(0.096)$ & $(0.329)$ \\
\hline \multirow{2}{*}{ Zambia } & -0.232 & -0.076 & 0.056 & $0.733^{* *}$ \\
\hline \multirow{2}{*}{ Nigeria } & $(0.315)$ & $(0.867)$ & $(0.749)$ & $(0.016)$ \\
\hline \multirow{2}{*}{ Angola } & 0.292 & 0.207 & 0.220 & 0.216 \\
\hline \multirow{2}{*}{ Algeria } & $(0.613)$ & $(0.708)$ & $(0.549)$ & $(0.387)$ \\
\hline \multirow{2}{*}{ Zimbabwe } & 0.956 & -0.125 & $1.091^{* *}$ & 0.488 \\
\hline \multirow{2}{*}{ Ghana } & $(0.169)$ & $(0.909)$ & $(0.051)$ & $(0.160)$ \\
\hline \multirow{2}{*}{ Kenya } & $4.585^{*}$ & $4.184^{*}$ & 0.471 & $0.408^{* *}$ \\
\hline \multirow{2}{*}{ Tanzania } & $(0.000)$ & $(0.000)$ & $(0.232)$ & $(0.033)$ \\
\hline & $1.718^{*}$ & $1.246^{* * *}$ & $-0.737^{* * *}$ & -0.441 \\
\hline \multirow{2}{*}{$* .002)$} & $(0.077)$ & $(0.086)$ & $(0.140)$ \\
\hline & $-0.697^{* * *}$ & $-1.866^{* *}$ & $1.896^{*}$ & 0.038 \\
& $(0.081)$ & $(0.033)$ & $(0.003)$ & $(0.888)$ \\
\hline & 0.598 & $0.868^{* * *}$ & 0.278 & -0.202 \\
& $(0.105)$ & $(0.081)$ & $(0.466)$ & $(0.539)$ \\
\hline & 0.277 & $1.783^{* *}$ & $-1.665^{* *}$ & -0.232 \\
& $(0.430)$ & $(0.014)$ & $(0.042)$ & $(0.615)$ \\
\hline
\end{tabular}

${ }^{*},{ }^{*}$ and ${ }^{* *}$ represent the $0.01,0.05$ and 0.10 significance levels, respectively.

Source: Authors' calculations

Finally, when the results of Model 4 in Table 13 are analysed, it is seen that GDP has a positive effect in Algeria and Zimbabwe and trade openness has a positive effect in Algeria, Zimbabwe, Kenya and Tanzania. When the coefficient of the LogResources 
variable $\beta_{3}$ is examined, it is seen that natural resource rents have a positive impact on Chinese foreign direct investments in South Africa and Angola, while they have a negative impact in the Democratic Republic of Congo, Zimbabwe and Tanzania. When the coefficient of the "regulatory quality" indicator is examined, it is seen that the effect of this variable on Chinese investments is positive in Zambia and Algeria. However, it does not have a significant impact in South Africa. The results regarding South Africa are not results that might have been expected since China has the highest foreign direct investment stock in this country and is increasing it. Natural resource rents have the highest impact in Ghana in comparison with Angola and South Africa although GDP and trade openness of this country have a negative impact. It can be evaluated as evidence of the power of the resource-seeking purposes of China in Africa.

\section{Conclusion}

In this study, the aim was to investigate the economic and institutional determinants of the increase in China's presence through foreign direct investments in Africa in recent years. For this purpose, some economic and institutional indicators were selected as the determinants of foreign direct investment. Since the selected economic indicators, namely GDP, trade openness and natural resource rents, are expected to affect foreign direct investment positively, the coefficients of these variables are expected to be positive. When the findings are examined, it is seen that GDP is positive and statistically significant in some countries in all the models established. This result shows that as the economic size increases in these African countries, China's direct foreign capital stock increases. Therefore, it can be stated that China evaluates these countries as markets. In countries where the effect of the trade openness variable on foreign direct investments is also statistically significant, the coefficients are found to be positive (except Ghana in all the models). In other words, the strengthening of trade relations between African countries and the global economy has a strengthening effect on China's foreign direct investment transfer to the region. When the results of the GDP and trade openness variables are evaluated together, it can be stated that China is approaching African countries in order to find markets and increase their interaction with the global economy according to standard economic theory. These results are what is to be expected theoretically taking into consideration the typical pull factors of foreign direct investments.

When it comes to the impact of natural resource rents on Chinese foreign direct investments, it is seen that this impact varies from country to country. However, it is noteworthy that natural resource rents in South Africa have a positive impact on Chinese foreign direct investments in each model, while natural resource rents in Tanzania have 
a negative impact on Chinese foreign direct investments in each model. It is observed in Appendix 2 that both South Africa and Tanzania have an increasing share of natural resource rents in GDP. However, South Africa is the country that has the highest share of Chinese foreign direct investments, while Tanzania is the country with the lowest share among the ten countries examined (Figure 2). Therefore, the result obtained for South Africa, as the country with the highest foreign direct investments from China, is noteworthy for showing that natural resource rents are attractive for Chinese FDI. The results obtained for Ghana, Kenya, Angola and Algeria also confirm the close symmetry between Chinese foreign direct investments and natural resource rents. This result also supports the claim discussed in the paper that China enters into partnerships and holds high shares in its investments. It can be interpreted accordingly that China's interest in the Africa continent increases as the share of the economic rent from the investments increases. Ghana gives evidence of this issue such that the natural resource rents in this country have the highest impact on Chinese FDI when compared to other countries although its GDP and trade openness levels have a negative impact on Chinese FDI. Hence, rents are more determinative of Chinese FDI than GDP and trade openness in this country, which is among the top ten countries attracting Chinese FDI.

On the other hand, institutional indicators have shown results that both support and contradict theoretical expectations. The variables of voice and accountability, control of corruption, rule of law and regulatory quality do not have a statistically significant impact in South Africa, where China has the largest share of its foreign direct investment stock. When this result is evaluated together with the downward trend of South Africa's institutional indicators in the period 2003-2017 (Appendix 1), it is concluded that the Chinese investment stock in this country has increased during the period when South Africa's institutional indicators have worsened. It is not possible to explain from general economic theory the increase in foreign direct investments and its associated risks in a country whose institutional structure is declining. If we recall the sectoral breakdown of China's foreign direct investments in Africa and that the construction and mining sectors were the top two sectors (Table 1), this result can be interpreted such that China increases its foreign direct investments in Africa for neo-mercantilist purposes.

Of these countries, it is particularly important to examine South Africa, since this is also the country with the highest level of foreign direct investment stock coming to the region from China. When the results obtained from the four models are evaluated, it is seen that China has increased its foreign direct investment in South Africa despite the deterioration of institutional indicators in this country. In the period under analysis, South Africa's institutional indicators have been on a downward trend (Appendix 1). Even if these indicators do not have a significantly negative impact on Chinese FDI, 
the only significant indicator which has an impact on Chinese FDI in South Africa is natural resource rents. When all these findings are considered together, it can be concluded that the reasons that China has been increasing its foreign direct investments in such a risky region are not in line with the strategic asset-seeking and efficiency-seeking purposes stated by Zhang and Kangombe. The positive impact of African countries' GDP and trade openness on China's foreign direct investment confirms the idea of marketseeking. In addition, depending on the impact of natural resource rents on foreign direct investments from China, it can also be stated that China's investments in this region are based on resource-seeking endeavours. As a result, the results obtained from the study support the "chopsticks" mercantilism view that is applied to Chinese investments and Chinese interaction on the African continent.

\section{Apendix}

\section{Appendix 1: Development of institutional quality in African countries (2013-2017)}

South Africa

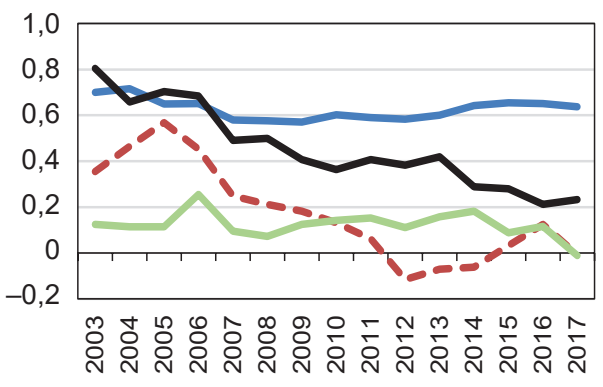

Zambia

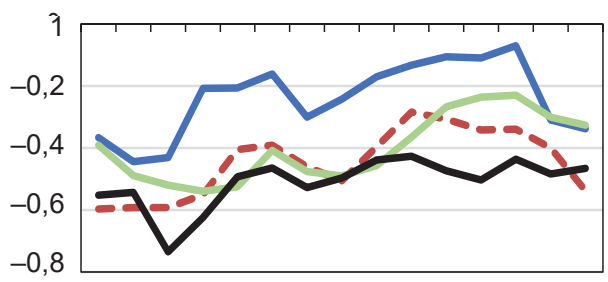

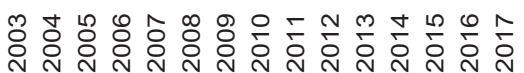

Democratic Republic of Congo

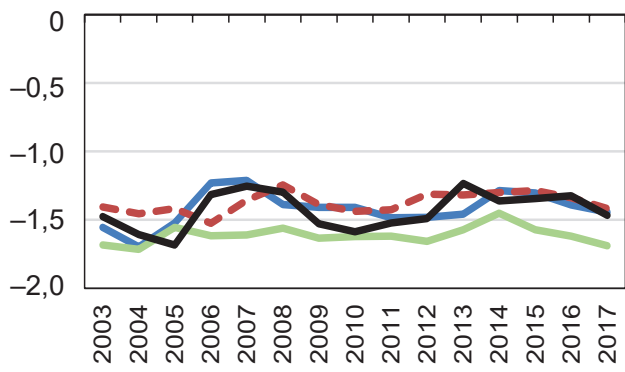

Nigeria

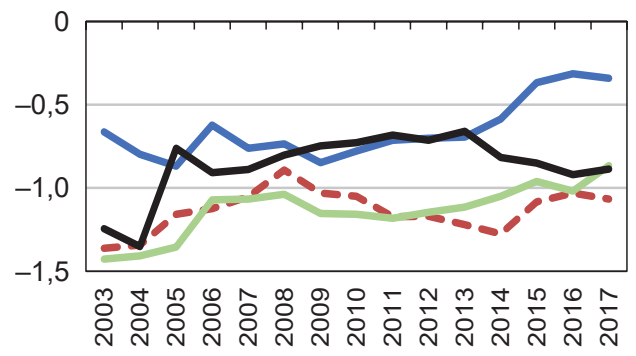

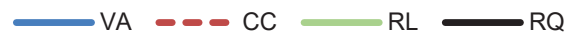


Angola

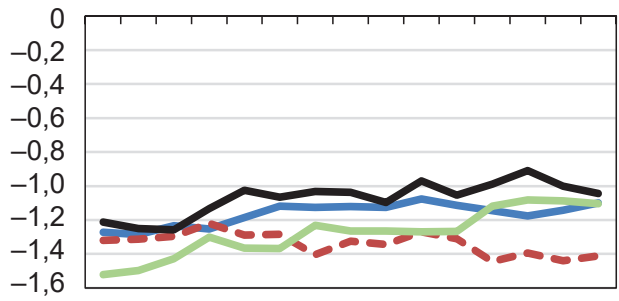

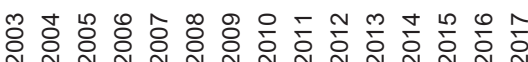

Zimbabwe

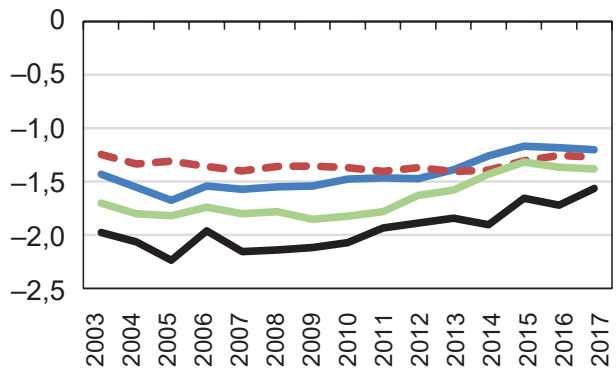

Kenya

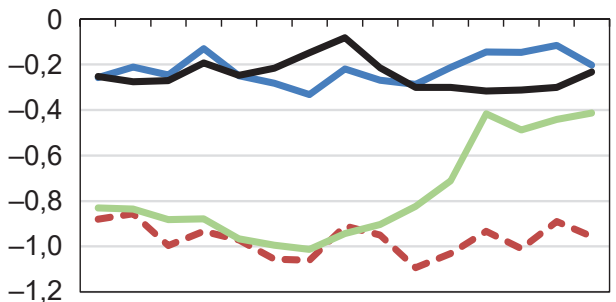

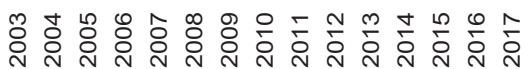

Algeria

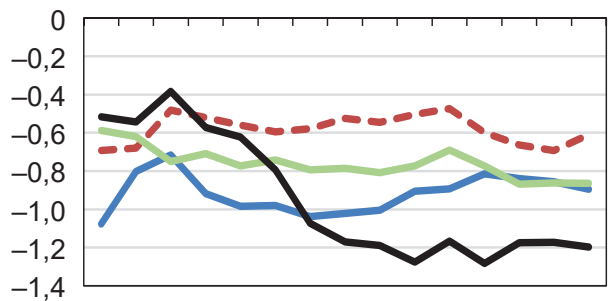

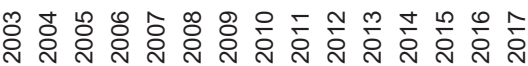

\section{Ghana}

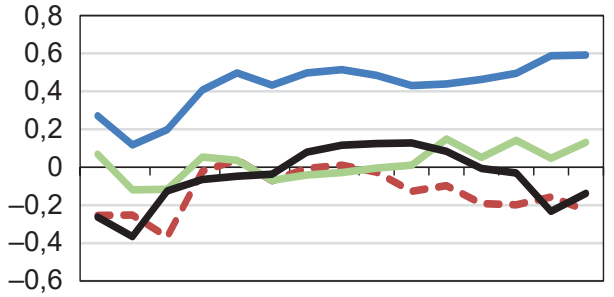

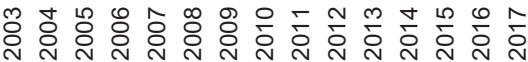

\section{Tanzania}

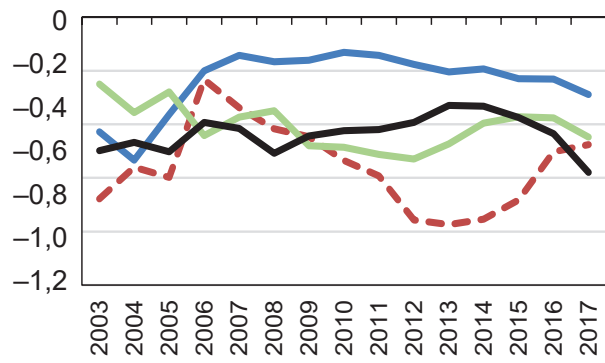

$\longrightarrow \mathrm{VA}=-\mathrm{CC} \longrightarrow \mathrm{RL} \rightleftharpoons \mathrm{RQ}$ 


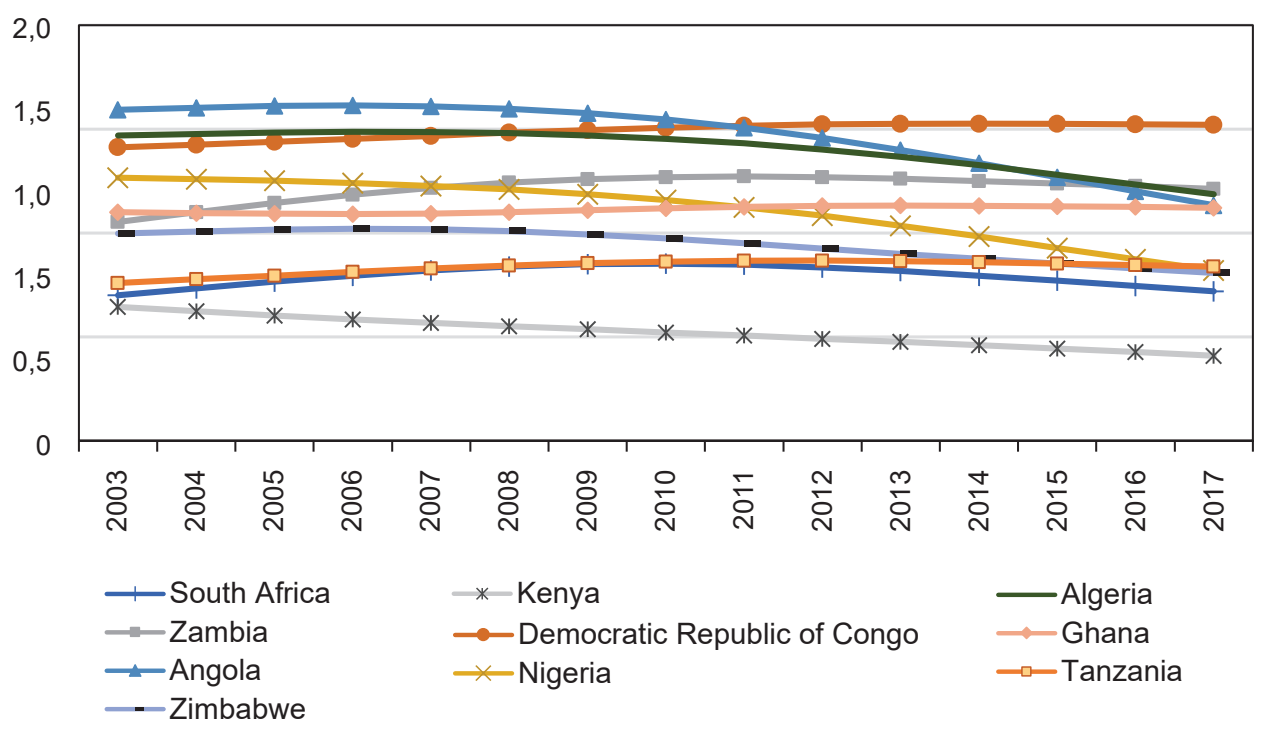

Note: The series represent trend values filtered using the Hodrick-Prescott method.

Source: World Bank

\section{References}

Adinda, S. (2018). Determinants of FDI in Africa - The Role of Agglomeration in Africa's Performance of Attracting FDI. Essay in Economics. Lund: Lund University School of Economics and Management. Available at: http://lup.lub.lu.se/luur/ download?func $=$ downloadFile\&recordOId $=8938825 \&$ fileOld $=8938827$

African Development Bank Group (2016). Catalyzing Growth and Development Through Effective Natural Resources Management. Abidjan: African Development Bank.Available at: https://www.afdb.org/fileadmin/uploads/afdb/Documents/Publications/anrc/ AfDB_ANRC_BROCHURE_en.pdf

Aglietta, M., Bai, G. (2016). China's 13th Five-year plan. In Pursuit of a 'Moderately Prosperous Society. Centre d'Etudes Prospectives et d'Informations Internationales (CEPII). Policy Brief No. 12. Available at: http://www.cepii.fr/PDF_PUB/pb/2016/pb2016-12.pdf

Akrami, F. (2008). Foreign Direct Investment in Developing Countries: Impact on Distribution and Employment - a Historical, Theoretical and Empirical Study (PhD dissertation). Fribourg: University of Fribourg.

Al Mariam (2019). Chinese Investments in Africa: "Chopsticks Mercantilism”. Al Mariam's Commentaries. [Retrieved 2019-03-08] Available at: http://almariam.com/2017/09/27/ chinese-investments-in-africa-chopsticks-mercantilism/ 
Asian Development Bank (2011). Asian Development Outlook 2011 - South-South Economic Links. Philippines: Asian Development Bank (ADB).

Atagenç, Ö. (2012). 'Çin ve Hindistan'ın deniz stratejisi ve Hint Okyanusu'nda güç mücadelesi'. Bilge Strateji, 4(6), 135-166 . (for author:please fill name in English - see at Refence style in web PE)

Aykut, D., Ratha, D. (2004). South-South FDI Flows: How Big Are They. Transnational Corporations, 13(1), 149-177.

Balcı, Z. (2018). 'Çin'in ipek yolu projesi'. (Silk Road Project of China) INSAMER, (52).

Besherati, N. A., MacFeely, S. (2019). Defining and Quantifying South-South Cooperation. UNCTAD. Geneva Research Paper No. 30.

Bloomberg [Retrieved 2019-03-08] Available at: https://www.bloomberght.com/cin-buyumebeklentisini-dusurdu-ve-vergi-indirimine-gitti-2201569 (for author: specify citation)

Borrmann, C., Jungnickel, R., Keller, D. (2005). What Gravity Model Can Tell Us About the Position of German FDI in Central and Eastern Europe. HWWA. Hamburg Discussion Paper No. 328, https://doi.org/10.2139/ssrn.798924

Breivik, A. L. (2014). Determinants of Chinese FDI in Africa: An Econometric Analysis (Master Thesis). Bergen: University of Bergen.

Busse, M., Erdogan, C., Mühlen, H. (2014). China's Impact on Africa - The Role of Trade, FDI and Aid. Institute of Development Research and Development. Policy Working Paper, https://doi.org/10.2139/ssrn.2426106

China-Africa Research Initiative (2019). Data: Chinese Investment in Africa. China Africa Research Initiative at Johns Hopkins University's. [Retrieved 2019-07-30] Available at: http://www.sais-cari.org/chinese-investment-in-africa

Claassen, C., Loots, E., Bezuidenhout, H. (2011). Chinese Foreign Direct Investment in Africa. North-West University. Working Paper No. 261.

Congressional Research Service (2019). China's Economic Rise: History, Trends, Challenges, and Implications for the United States. Washington, DC: Congressional Research Service. [Retrieved 2019-08-28] Available at: https://fas.org/sgp/crs/row/RL33534.pdf

FDI China (2019). Expat and Local Wages in China. Shanghai: FDI China. [Retrieved 2019-08-19] Available at: https://www.fdichina.com/blog/wages-in-china/

Feinstein, A. (2015). Decentralisation: the South African Experience. London: Global Partner Governance. Available at: https://gpg-wp-media.s3.eu-west-1.amazonaws.com/ wp-content/uploads/2015/07/09133005/Decentralisaion-the-south-african-experiencefeinstein 1.pdf

German Chamber of Commerce in China (2018). Labor Market \& Salary Report. 11 th edition, German Chamber of Commerce In China. [Retrieved 2019-08-19] Available at: https://china.ahk.de/fileadmin/AHK_China/Market_Info/Economic_Data/GCC-11thLabor-Market-and-Salary-Report-2018_short.pdf 
Gonzalez-Vicente, R. (2011). China's Engagement in South America and Africa's Extractive Sectors: New Perspectives for Resource Curse Theory. The Pacific Review, 24(1), 65-87, https://doi.org/10.1080/09512748.2010.546874

Hadri, K., Kurozumi, E. (2012), 'A Simple Panel Stationarity Test in the Presence of Serial Correlation and A Common Factor. Economic Letters, 115(1), 31-34, https://doi. org/10.1016/j.econlet.2011.11.036

Hsiao, C., Pesaran, M. H. (2004). Random Coefficient Panel Data Models. IZA - Institute of Labor Economics. Discussion Paper No. 1236.

KAS South Africa Office (n.d.) Decentralisation in South Africa. KAS South Africa Office. [Retrieved 2019-09-05]Available at: https://www.kas.de/c/document_library/get_ file?uuid=863bed83-602e-0d76-0d39-838b2ce2896e \& groupld=252038

Kaufmann, D., Kraay, A., Mastruzzi, M. (2010). The Worldwide Governance Indicators Methodology and Analytical Issues. The World Bank. Washington, D.C. Working Paper No. 5430, https://doi.org/10.1596/1813-9450-5430

Kokouma, D. M. S., Xu, K. (2013). Attracting Chinese Foreign Direct Investment (FDI) to Africa: Determinants and Policies - The Case of Guinea. International Journal of Financial Research, 4(4), 52-71, https://doi.org/10.5430/ijfr.v4n4p52

Landreth, H., Colander, D. (2002). History of Economic Thought. Toronto: Houghton Mifflin Company. Lieberman, E. S., Martin, P., McMurry, N. (2017). Politicians' Perspectives on Voice and Accountability: Evidence from a Survey of South African and Local Councillors. MIT. Political Science Research Report.

New York Times (2017). Is China the World's New Colonial Power? New York Times. 02.05. [Retrieved 2019-03-07] Available at: https://www.nytimes.com/2017/05/02/magazine/ is-china-the-worlds-new-colonial-power.html?_r=2

Nişancı, M., Sarı, S., Doker, A. C., et al. (2017). Lewis'in iki sektörlü büyüme modeline Çin özelinde bakış: büyümenin sınırlarına gelindi mi? (Outlook on Lewis dual sector model of economic growth specific to China: is it the limit of growth?) In International Conference on Economics Finance and Banking, Istanbul-Turkey, 15-16 July 2017.

North, D. C. (1991). Institutions. The Journal of Economic Perspectives, 5(1), 97-112.

Okeke, D. (2016). Integrated Productivity in Urban Africa: Introducing the Neo-mercantile Planning Theory. Switzerland: Springer International Publishing. ISBN 978-3-319-41829-2.

Pambazuka News (2019). Chinese Investments in Africa: Chopsticks Mercantilism. Pambazuka News. 05.10. [Retrieved 2019-03-07] Available at: https://www.pambazuka.org/ emerging-powers/chinese-investments-africa-chopsticks-mercantilism

Pan, C., Chang, T., Wolde-Rufael, Y. (2015). Military Spending and Economic Growth in the Middle East countries: Bootstrap Panel Causality Test. Defence and Peace Economics, 26(4), 443-456, https://doi.org/10.1080/10242694.2014.891356

Pesaran, M. H. (2004). General Diagnostic Tests for Cross Section Dependence in Panels. University of Cambridge, Faculty of Economics. Cambridge Working Papers in Economics No. 0435. 
Poi, B. P. (2003). From the Help Desk: Swamy's Random-coefficient Model. The Stata Journal, 3(3), 302-308, https://doi.org/10.1177/1536867X0300300307

Ross, A. G., Omar, M., Xu, A., et al. (2019). The Impact of Institutional Quality on Chinese Foreign Direct Investment in Africa. Local Economy: The Journal of the Local Economy Policy Unit, 34(6), 572-588, https://doi.org/10.1177/0269094219882329

Savaş, V.F. (2016). Bilmediğimiz Çin. (Unknown China.) Ankara: Efil Yayınevi. ISBN 978-605-4160-72-3.

Scobell, A., Lin, B., Shatz, H. J., et al. (2018). At the Dawn of Belt and Road - China in the Developing World. California: RAND Corporation. ISBN 9780833099914.

Sichei, M. M., Kinyondo, G. (2012). Determinants of Foreign Direct Investment in Africa: A Panel Data Analysis. Global Journal of Management and Business Research, 12(18), 85-97.

Swamy, P. A. V. B. (1970). Efficient Inference in a Random Coefficient Regression Model. Econometrica, 38(2), 311-323, https://doi.org/10.2307/1913012

Taylor, M. P., Sarno, L. (1998). The Behavior of Real Exchange Rates During the Post-Bretton Woods Period. Journal of International Economics, 46(2), 281-312, https://doi.org/10.1016/s0022-1996(97)00054-8

Topal, M., Eyduran, E., Yağanoğlu, A. M., et al. (2010). Çoklu doğrusal bağlantı durumunda Ridge ve temel bileşenler regresyon analiz yöntemlerinin kullanımı. (Usage of Ridge and principal component regression analysis methods in case of multicollinearity.) Atatürk Üniversitesi Ziraat Fakültesi Dergisi, 41(1), 53-57.

Trading Economics (2019). Wages in Manufacturing in China Increased to 78147 CNY/Year in 2019 from 72088 CNY/Year in 2018. Trading Economics. [Retrieved 2019-08-19] Available at: https://tradingeconomics.com/china /wages-in-manufacturing

UNCTAD Secreteriat (2005). Emerging FDI from Developing Countries. In United Nations Conference on Trade and Development, March 2005. Geneva: UNCTAD Secreteriat.

UNCTAD (2010). Economic Development in Africa: South-South Cooperation: Africa and the New Forms of Development Partnership. Geneva: United Nations Conference on Trade and Development. Available at: https://unctad.org/en/Docs/tdb57d2_en.pdf

UNDP (2016). Scaling-up South-South Cooperation for Sustainable Development. New York, NY: United Nations Development ProgrammeBureau for Policy and Programme Support. Available at: file:///C:/Users/KATEIN 1/AppData/Local/Temp/11960\%20-\%20Design\%20 for\%20Scaling-up\%20South-South\%20Cooperation\%20for\%20Sustainable\%20 Development\%20-\%2009-3_Web.pdf

World Bank (2019a). GDP Growth (Annual \%). Washington, D.C.: World Bank. [Retrieved 2019-03-09] Available at: https://data.worldbank.org/indicator/ NY.GDP.MKTP. $\mathrm{KD} . \mathrm{ZG}$ ?locations=CN

World Bank (2019b). Consumer Price Index $(2010=100)$ - China. Washington, D.C.: World Bank. [Retrieved 2019-08-28] Available at: https://data.worldbank.org/indicator/ FP.CPI. TOTL?locations $=\mathrm{CN}$ 
World Bank (2019c). The Worldwide Governance Indicators (WGI). Washington, D.C.: World Bank. [Retrieved 2019-07-30] Available at: https://info.worldbank.org/governance/ wgi/\#doc

World Bank (2020). Metadata Glossary. Washington, D.C.: World Bank. [Retrieved 2020-07-08] Available at:https://databank.worldbank.org/metadataglossary/adjusted-net-savings/ series/NY.GDP.TOTL.RT.ZS

Yakubu, İ. N., Mikhail, A. A. (2019). Determinants of Foreign Direct Investment in Ghana: A Sectoral Analysis. Munich Personal RePEc Archive. Munich MPRA Paper No. 95121. Available at: https://mpra.ub.uni-muenchen.de/95121/1/MPRA_paper_95121.pdf

Yerdelen Tatoğlu, F. (2013). Ileri panel veri analizi Stata uygulamalı. (Advanced panel data analysis with Stata.) Istanbul: Beta.

Zhang, Q., Kangombe, A. (2016). Chinese Investment in Africa: How the New Normal Can Leverage Agenda 2063 for Sustainable Economic Co-operation. African - East Asean Affairs, 3,:60-95, https://doi.org/10.7552/0-3-177

Ziegler, C. E., Menon, R. (2014). Neomercantilism and Great-power Energy Competition in Central Asia and the Caspian. Strategic Studies Quarterly, 38(4), 17-41. Available at: https://ir.library.louisville.edu/cgi/viewcontent.cgi?article=1056\&context=faculty 